\title{
Cell-Mediated Immunity in Acute and Chronic Hepatitis
}

\author{
J. R. Wands, J. L. Perrotto, E. Alpert, and K. J. Isselbacher \\ From the Departments of Medicine, Harvard Medical School, and the \\ Gastrointestinal Unit, Massachusetts General Hospital, \\ Boston, Massachusetts 02114
}

A B S T R A C T Peripheral lymphocytes from patients with hepatitis-B surface antigen $\left(\mathrm{HB}_{\mathrm{s}} \mathrm{Ag}\right)$-positive and -negative acute hepatitis (AH), chronic active hepatitis $(\mathrm{CAH})$, chronic persistent hepatitis $(\mathrm{CPH})$, and normal controls were tested for in vitro cytotoxicity and blast transformation. Cytotoxicity was measured by chromium $\left({ }^{15} \mathrm{Cr}\right)$ release into the medium from ${ }^{51} \mathrm{Cr}$ labeled Chang liver cells after incubation for $6 \mathrm{~h}$ with peripheral lymphocytes at a lymphocyte target cell ratio of $200: 1$. Concomitant 72 -h incubation studies were performed to assess thymus cell-dependent $(T)$ lymphocyte function as measured by concanavalin A (Con A)stimulated incorporation of tritiated thymidine (blast transformation) and by cytotoxicity. It was found that (a) lymphocytes from patients with $\mathrm{AH}$ are cytotoxic to Chang liver cells compared to controls $(P<0.001)$; (b) lymphocytes from patients with acute and chronic hepatitis are less cytotoxic when incubated with autologous and homologous $\mathrm{HB}$.Ag-positive serum; (c) lymphocytes from patients with $\mathrm{HB} . \mathrm{Ag}$-positive and -negative $\mathrm{AH}, \mathrm{CAH}$, and $\mathrm{CPH}$ are as cytotoxic as normal controls when stimulated with a nonspecific mitogen such as Con A; and (d) lymphocytes from patients with $\mathrm{CAH}$ while on prednisone therapy showed marked depression of cytotoxicity when stimulated with Con A. Thus these studies show that patients with $\mathrm{AH}$ have circulating $\mathrm{T}$ lymphocytes which are capable of causing the destruction of Chang liver cells. There is no defect in T-cell function as measured by Con Astimulated cytotoxicity. There is a serum factor(s) in patients with acute and chronic hepatitis which inhibits spontaneous and induced lymphocyte cytotoxicity and blast transformation. Finally, prednisone treatment appears to inhibit lymphocyte cytotoxicity in patients with CAH.

Presented in part at the American Gastroenterological Association Meetings, 24 May 1974, San Francisco.

Received for publication 25 July 1974 and in revised form 3 January 1975.

\section{INTRODUCTION}

Thymus-derived or T-lymphocyte ${ }^{1}$ function may be an important determinant in the host response to hepatitis infection (1-3). The persistence of hepatitis-B surface antigen ( $\mathrm{HB} . \mathrm{Ag}$ ) in the serum following an attack of hepatitis $B$ is frequently associated with the development of chronic active and chronic persistent hepatitis (4). Cell-mediated immunity in chronic carriers of hepatitis- $B$ antigen and in patients with chronic active hepatitis ( $\mathrm{CAH}$ ) has been reported to be abnormal when assessed by in vitro assays such as phytohemagglutinin (PHA)-stimulated lymphocyte blast transformation and leukocyte migration inhibition (1-3, 5). Thus, studies were performed to assess the role of $T$-lymphocyte function in patients with acute and chronic hepatitis and controls. Lymphocyte blastogenesis was measured by the incorporation of $\left[{ }^{3} \mathrm{H}\right]$ thymidine after stimulation with concanavalin A (Con A) and effector T-lymphocyte function was studied by both spontaneous and Con A-induced lymphocyte cytotoxicity. We also evaluated the importance of serum factors in the in vitro assessment of cellular immunity in these hepatitis patients. Finally, the in vivo effect of prednisone administration on lymphocyte function was investigated in vitro in patients with $\mathrm{CAH}$ because of the often observed clinical response of these patients to such therapy.

\section{METHODS}

Patients. 22 patients with acute and chronic hepatitis were studied. The clinical features of these patients at the time of study are shown in Table I. An additional nine healthy volunteers served as control subjects. All control subjects were found negative for $\mathrm{HB}, \mathrm{Ag}$ and surface hepatitis- $B$ antibody by hemagglutination and hemagglutination inhibition (6).

${ }^{1}$ Abbreviations used in this paper: $\mathrm{CAH}$, chronic active hepatitis; Con $\mathrm{A}$, concanavalin $\mathrm{A}$; $\mathrm{HB}_{\mathrm{s}} \mathrm{Ag}$, hepatitis-B surface antigen; PHA, phytohemagglutinin; $T$ lymphocyte, thymus-derived lymphocyte.

The Journal of Clinical Investigation Volume 55 May 1975.921-929 
TABLE 1

Clinical Data on Patients on the Day of Study

\begin{tabular}{|c|c|c|c|c|c|c|c|c|c|c|}
\hline $\begin{array}{l}\text { Case } \\
\text { no. }\end{array}$ & Age & Sex & $D x$ & SGOT & $\begin{array}{c}\text { Total } \\
\text { bilirubin }\end{array}$ & Jaundice & $\begin{array}{c}\mathrm{HB}_{\mathrm{z}} \mathrm{Ag} \\
\text { (RIA) }\end{array}$ & $\begin{array}{c}\text { Anti-HB } B_{\mathbf{s}} \\
\text { (HA) }\end{array}$ & Liver Dx & $\mathrm{Rx}^{*}$ \\
\hline & $y r$ & & & $I U$ & $\mathrm{mg} / 100 \mathrm{ml}$ & days $\neq$ & & & & \\
\hline 1 & 28 & $\mathbf{M}$ & $\mathrm{AH}$ & 1,600 & 6.8 & 4 & $\mathrm{Neg}$ & Pos & $\mathrm{AH}$ & - \\
\hline 2 & 22 & M & $\mathrm{AH}$ & 2,600 & 4.1 & 10 & Pos & Neg & - & - \\
\hline 3 & 30 & $\mathbf{M}$ & $\mathrm{AH}$ & 1,800 & 10.4 & 18 & Pos & $\mathrm{Neg}$ & - & - \\
\hline 4 & 21 & $\mathbf{M}$ & $\mathrm{AH}$ & 800 & 2.1 & 8 & Pos & Neg & - & - \\
\hline 5 & 56 & $\mathrm{~F}$ & $\mathrm{AH}$ & 2,800 & 26.0 & 16 & Pos & Neg & - & - \\
\hline 6 & 23 & $\mathbf{M}$ & $\mathrm{AH}$ & 2,400 & 6.8 & 10 & Pos & Neg & - & 一 \\
\hline 7 & 19 & $\mathrm{~F}$ & $\mathrm{AH}$ & 650 & 2.3 & 11 & Pos & Neg & - & - \\
\hline 8 & 24 & M & $\mathrm{AH}$ & 1,400 & 4.8 & 8 & Pos & Neg & - & - \\
\hline 9 & 28 & $\mathrm{~F}$ & $\mathrm{AH}$ & 3,800 & 14.4 & 12 & Pos & Neg & - & - \\
\hline 10 & 25 & M & $\mathrm{AH}$ & 2,700 & 5.0 & 7 & Pos & $\mathrm{Neg}$ & - & - \\
\hline 11 & 27 & $\mathbf{M}$ & $\mathrm{AH}$ & 1,900 & 3.0 & 9 & Pos & $\mathrm{Neg}$ & - & - \\
\hline 12 & 18 & M & $\mathrm{AH}$ & 3,800 & 6.2 & 10 & Pos & Neg & - & - \\
\hline 13 & 18 & $\mathbf{M}$ & $\mathrm{AH}$ & 340 & 4.2 & 9 & Pos & Neg & - & - \\
\hline 14 & 22 & M & $\mathrm{AH}$ & 600 & 3.1 & 7 & Pos & Neg & - & - \\
\hline 15 & 28 & M & $\mathrm{AH}$ & 128 & 1.8 & 16 & Neg & Neg & - & - \\
\hline 16 & 63 & M & $\mathrm{CAH}$ & 240 & 35.0 & - & Neg & $\mathrm{Neg}$ & $\mathrm{CAH}$ with cirrhosis & $30 \mathrm{mg}$ Pred/day \\
\hline 17 & 28 & $\mathrm{~F}$ & $\mathrm{CAH}$ & 380 & 1.0 & - & Neg & Neg & CAH with cirrhosis & $40 \mathrm{mg}$ Pred/day \\
\hline 18 & 42 & M & $\mathrm{CAH}$ & 160 & 1.0 & - & Pos & Neg & $\mathrm{CAH}$ & $30 \mathrm{mg}$ Pred/day \\
\hline 19 & 19 & M & $\mathrm{CAH}$ & 400 & 2.3 & - & Pos & Neg & $\mathrm{CAH}$ & $60 \mathrm{mg}$ Pred/day \\
\hline 20 & 19 & M & $\mathrm{CAH}$ & 350 & 1.9 & 一 & Pos & Neg & $\mathrm{CAH}$ & $60 \mathrm{mg}$ Pred/day \\
\hline 21 & 25 & M & $\mathrm{CPH}$ & 80 & 1.0 & 一 & Pos & Neg & $\mathrm{CPH}$ & - \\
\hline 22 & 21 & M & $\mathrm{CPH}$ & 71 & 1.0 & - & Neg & Pos & $\mathrm{CPH}$ & - \\
\hline
\end{tabular}

$\mathrm{AH}$, acute hepatitis; anti- $\mathrm{HB}_{\mathbf{s}}$, hepatitis-B surface antibody; $\mathrm{CPH}$, chronic persistent hepatitis; Pred, prednisone; SGOT serum glutamic oxaloacetic transaminase.

* Three patients studied before prednisone therapy.

$\ddagger$ Number of days jaundice present at the time of study.

Isolation of lymphocytes. $30-50 \mathrm{ml}$ of heparinized venous blood from patients and a control were collected in plastic syringes and allowed to sediment at $37^{\circ} \mathrm{C}$ for $90 \mathrm{~min}$. The leukocyte-rich plasma was pipetted off and placed over sterile glass wool packed in $30-\mathrm{cm}^{3}$ glass syringes. The column was then washed with $100 \mathrm{ml}$ of Hanks' balanced salt solution. The resultant cell suspension was centrifuged, washed twice, and resuspended in $10 \mathrm{ml}$ of RPMI medium supplemented with $10 \%$ heat-inactivated fetal calf serum, 40 mmol glutamine plus $100 \mathrm{U}$ penicillin and $100 \mu \mathrm{g}$ streptomycin (complete medium). The cell suspensions were counted and contained $95-98 \%$ small lymphocytes, $2-5 \%$ monocytes, and numerous red blood cells. Lymphocyte viability was determined by trypan blue exclusion and was found to be $95 \%$. The final concentration of lymphocytes was adjusted to 1 $\times 10^{\circ}$ cells $/ \mathrm{ml}$.

Preparation of target cells. Chang cells, a human-derived epithelioid liver cell line (Microbiological Associates, Bethesda, Md.), were continuously cultivated in plastic petri dishes containing complete RPMI medium at $37^{\circ} \mathrm{C}$ and in an atmosphere of $95 \%$ air and $5 \%$ carbon dioxide. Cells were harvested by trypsinization, yielding single cell suspensions which were concentrated by centrifugation at 1,000 $\mathrm{rpm}$. Chang liver cells $\left(1 \times 10^{8}\right)$ were suspended in $5 \mathrm{ml}$ of complete RPMI medium and incubated with $300 \mu \mathrm{Ci}$ of radioactive sodium chromate $\left({ }^{51} \mathrm{Cr}\right)$ for $45 \mathrm{~min}$ at $37^{\circ} \mathrm{C}$. The cells were then washed three times with $30 \mathrm{ml}$ of com- plete medium, counted, and rechecked for viability with trypan blue. The final concentration of target cells was adjusted to $1 \times 10^{4}$ cells $/ \mathrm{ml}$.

Blast transformation. 2 million human peripheral lymphocytes were suspended in $2.0 \mathrm{ml}$ of complete RPMI media. Triplicate cultures were set up for each group and incubated at $37^{\circ} \mathrm{C}$ for $72 \mathrm{~h}$ in the presence of $10 \%$ carbon dioxide. 18 $\mathrm{h}$ before termination of the incubation, $2 \mu \mathrm{Ci}$ of $\left[{ }^{3} \mathrm{H}\right]-$ thymidine (sp act $20 \mathrm{Ci} / \mathrm{mmol}$ ) in $0.1 \mathrm{ml}$ of tissue culture media was added to each tube. At $72 \mathrm{~h}$, the tubes were washed three times in ice-cold normal saline. Subsequently, $5.0 \mathrm{ml}$ of ice-cold $5 \%$ TCA was added to the cell pellet and this was poured onto glass fiber filters ( $H$. Reeve Angel \& Co. Inc., Clifton, N. J.). The filters were washed once with $5.0 \mathrm{ml}$ of $5 \%$ TCA with vacuum suction, dried with 10.0 $\mathrm{ml}$ of absolute ethanol, placed in $10 \mathrm{ml}$ of toluene POPOP (1,4-bis[2-(5-phenyloxazoly1)]benzene) scintillant, and counted in a Beckman scintillation counter. The mean counts per minute for $2 \times 10^{6}$ lymphocytes and the standard errors of the mean were calculated.

Cytotoxicity studies. $2 \mathrm{ml}$ of $1 \times 10^{\circ}$ lymphocytes $/ \mathrm{ml}$ were added to $1 \mathrm{ml}$ of $1 \times 10^{4}$ labeled Chang liver cells to yield a lymphocyte target cell ratio of 200 to 1 . These suspensions were incubated on a rocker platform for $6 \mathrm{~h}$ at $37^{\circ} \mathrm{C}$ under a $95 \%$ air, $5 \%$ carbon dioxide atmosphere. At the end of the incubation period, the cell suspensions were transferred from $35 \times 25-\mathrm{mm}$ plastic petri dishes to small 
test tubes and centrifuged at $1,000 \mathrm{rpm}$ for $15 \mathrm{~min}$. The supernate was carefully decanted into counting tubes and counted in duplicate by a three-channel Packard gamma counter (Packard Instrument Co., Inc., LaGrange, Ill.). The mean counts per 5 min released from $1 \times 10^{4}$ Chang cells and standard error of the mean were calculated. Cytotoxicity was measured by ${ }^{51} \mathrm{Cr}$ release into the medium from ${ }^{51} \mathrm{Cr}$-labeled Chang liver cells after incubation with peripheral lymphocytes. The percent cytotoxicity was expressed as the mean number of counts released from Chang cells in the presence of lymphocytes, minus spontaneous release of ${ }^{51} \mathrm{Cr}$ from the Chang cells, divided by the total number of releasable counts, as determined by freeze-thawing the Chang cells.

Study design. Concomitant $72-\mathrm{h}$ incubation studies were performed to assess lymphocyte blastogenesis and T-lymphocyte function as measured by Con A-stimulated incorporation of tritiated thymidine and by cytotoxicity. The importance of serum factors on in vitro lymphocyte function was evaluated in the hepatitis patients by using the following incubation conditions: lymphocytes alone, lymphocytes plus autologous serum, lymphocytes plus $\mathrm{HB}_{\mathrm{s}} \mathrm{Ag}$-positive homologous serum, lymphocytes plus Con A and autologous serum, and lymphocytes plus purified $\mathrm{HB}_{\mathbf{s}} \mathrm{Ag}$. Additionally, lymphocytes obtained from acute hepatitis patients were stimulated with $C$ on $A$ in the presence and absence of normal serum to determine the effect of such serum on lymphocyte blastogenesis and cytotoxicity. Finally, the effect of homologous $\mathrm{HB}_{\mathbf{s}} \mathrm{Ag}$-positive hepatitis serum on normal lymphocyte function (control lymphocytes) was studied in the presence and absence of Con $\mathrm{A}$.

Autologous serum from patients and controls was obtained on the day of study and added to the incubation medium at a concentration of $5 \%$. Homologous $\mathrm{HB}_{\mathbf{s}} \mathrm{Ag}-$ positive serum from seven patients with acute hepatitis and two patients with $\mathrm{CAH}$ was collected, divided into aliquots, and stored at $-70^{\circ} \mathrm{C}$. On the day of study, it was thawed

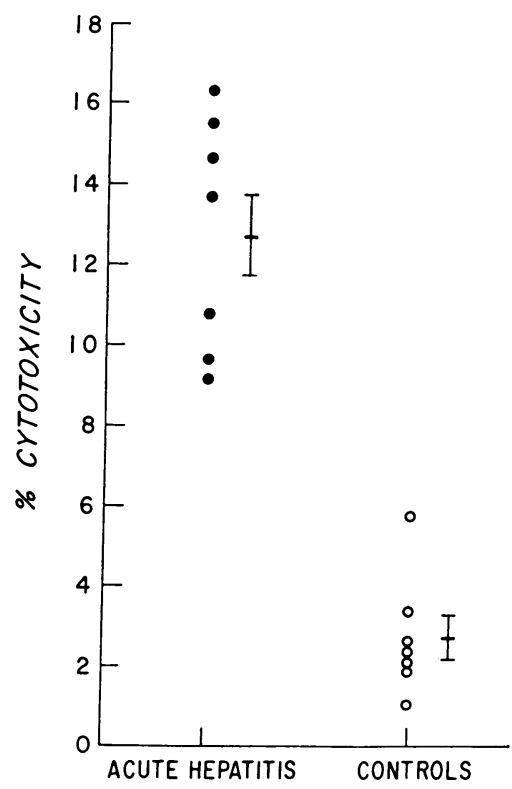

Figure 1 The difference in spontaneous lymphocyte cytotoxicity between patients with acute viral hepatitis compared to control lymphocytes (6-h incubation).

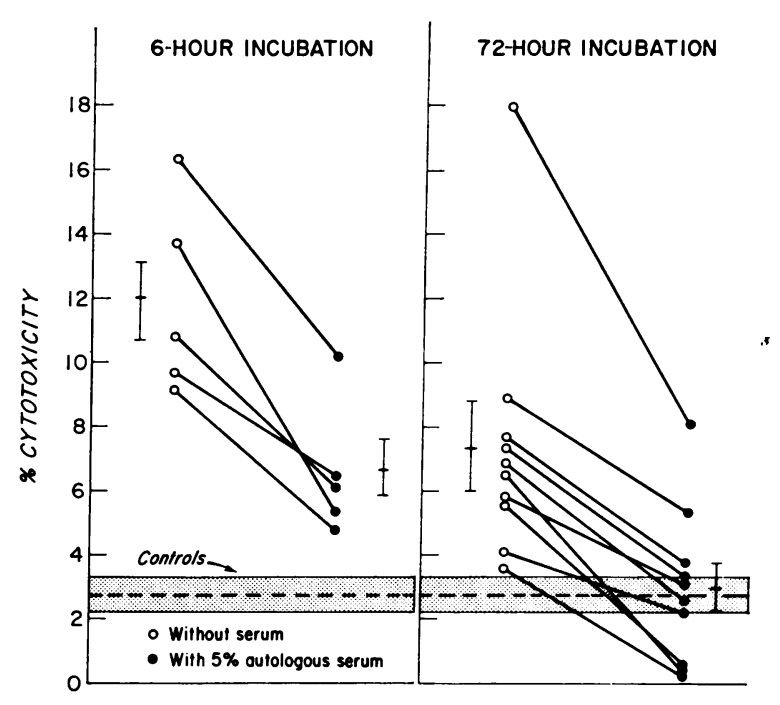

Figure 2 The depressive effect of $5 \%$ autologous serum on spontaneous lymphocyte cytotoxicity in acute viral hepatitis. Note that $5 \%$ autologous serum does not completely depress all 6-h spontaneous lymphocyte cytotoxicity when compared to control lymphocytes.

and added to the incubation medium at a concentration of 5\%. Con A (Miles Laboratories, Inc., Kankakee, Ill.) was added at a previously determined optimal concentration of $10 \mu \mathrm{g} / \mathrm{ml}$. $\mathrm{HB}_{\mathrm{s}} \mathrm{Ag}$ (lot no. 143-76) purified by cesium chloride ultracentrifugation was obtained from ElectroNucleonics Corporation (Bethesda, Md.). This preparation had a particle count of $1.6 \times 10^{14} / \mathrm{ml}$, agar gel diffusion titer of $1: 16$, nitrogen content of $0.0533 \mathrm{mg} / \mathrm{ml}$, and contained no albumin or gamma globulin by counter electrophoresis or Ouchterlony gel diffusion. Purified $\mathrm{HB}_{\mathbf{B}} \mathrm{Ag}$ was added to the incubation medium undiluted and at $1: 10$, $1: 100$, and $1: 1,000$ dilutions.

Statistical analysis. The geometric mean of blast transformation and percent cytotoxicity at 6 and $72 \mathrm{~h}$ for experimental and control groups were compared by applying the Student's $t$ test.

\section{RESULTS}

Spontaneous lymphocyte cytotoxicity in acute viral hepatitis. Peripheral lymphocytes from patients with acute viral hepatitis were spontaneously cytotoxic to human Chang liver cells when tested at a lymphocyte target cell ratio of $200: 1$. Lymphocytes from seven patients and seven normal controls were incubated with target cells for $6 \mathrm{~h}$ in this experiment. The mean spontaneous lymphocyte cytotoxicity in patients with acute hepatitis was $12.71 \pm 1.06 \%$ as compared to $2.71 \pm$ $0.53 \%(P<0.001)$ in normal control individuals (Fig. 1).

Effect of autologous and homologous HB.Ag-positive serum on spontaneous lymphocyte cytotoxicity in acute viral hepatitis and controls. Spontaneous lymphocyte cytotoxicity in patients with acute hepatitis is significantly depressed $(P<0.01)$ when incubated in their 


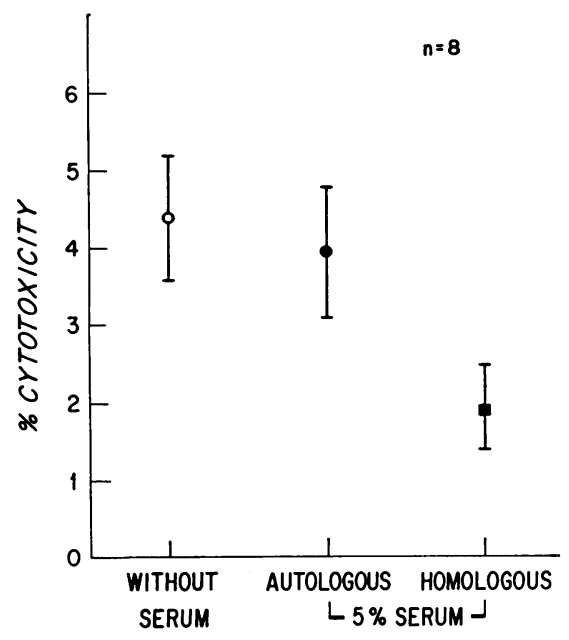

FIGURE 3 Effect of various sera on spontaneous lymphocyte cytotoxicity in eight healthy controls. There was a twofold inhibition of lymphocyte cytotoxicity when incubated in the presence of $5 \% \mathrm{HB}_{\mathbf{3}} \mathrm{Ag}$-positive homologous serum (72-h incubation).

own serum. The addition of $5 \%$ autologous serum to lymphocytes from patients with acute viral hepatitis lowers the cytotoxicity from 12 to $5 \%(P<0.05)$ after $6 \mathrm{~h}$ incubation. This depression of cytotoxicity by autologous sera is also seen after 72 -h incubations as shown in Fig. 2. Autologous serum completely inhibits all spontaneous lymphocyte cytotoxicity after $72 \mathrm{~h}$ incubation. Controls were unchanged after the addition of autologous normal sera.

The effect of $5 \%$ homologous $\mathrm{HB}$ sg-positive serum on spontaneous lymphocyte cytotoxicity (72-h incubation) was also studied in seven patients with acute viral hepatitis. In these patients, the mean percent spontaneous lymphocyte cytotoxicity in the absence of human sera was $7.33 \pm 1.35$, which fell to $3.5 \pm 0.96(P<$ 0.05 ) in the presence of homologous serum (Table II).

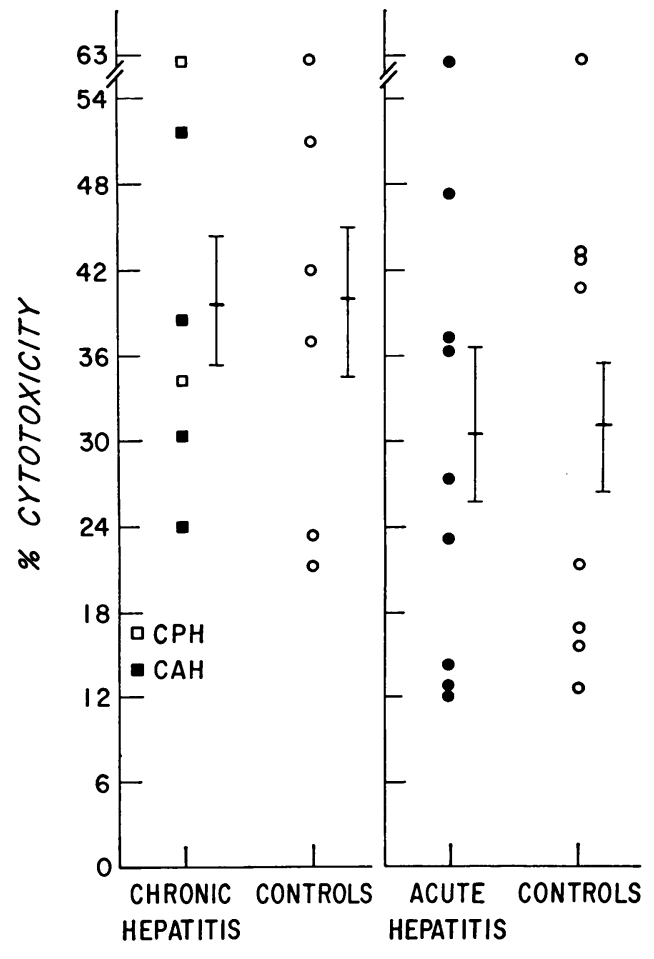

FIgURE 4 A comparison of Con A-maximally stimulated lymphocyte cytotoxicity between acute hepatitis, chronic persistent hepatitis $(\mathrm{CPH}), \mathrm{CAH}$, and controls (72-h incubation).

Autologous normal serum did not inhibit spontaneous lymphocyte cytotoxicity in eight control individuals as shown in Fig. $3(P<0.5)$. There was, however, a significant inhibition of the low level of spontaneous lymphocyte cytotoxicity when normal peripheral lymphocytes were incubated for $72 \mathrm{~h}$ in the presence of $5 \%$ HBs.Ag-positive homologous serum. Lymphocyte cytotoxicity fell from $4.41 \pm 0.85 \%$ to $1.98 \pm 0.48 \%$ in the

TABLE II

Percent Lymphocyte Cytotoxicity in Acute Hepatitis, CAH, and Controls (72-h Incubation)

\begin{tabular}{|c|c|c|c|}
\hline \multirow[b]{2}{*}{ Incubation conditions } & \multicolumn{3}{|c|}{ Diagnosis } \\
\hline & Acute hepatitis & $C A H$ & Controls \\
\hline Lymphocytes alone (spontaneous) & $7.33 \pm 1.35(7)$ & $6.75 \pm 0.86(4)$ & $3.92 \pm 0.72(10)$ \\
\hline Autologous serum & $2.89 \pm 0.75(7)$ & $1.15 \pm 0.55(4)$ & $3.78 \pm 0.85(10)$ \\
\hline Homologous $\mathrm{HB}_{\mathrm{s}} \mathrm{Ag}$-positive serum & $3.50 \pm 0.96(7)$ & $4.30 \pm 0.30(4)$ & $1.94 \pm 0.68(10)$ \\
\hline Con A stimulation & $32.70 \pm 6.94(6)$ & $34.00 \pm 8.73(4)$ & $36.04 \pm 7.61(10)$ \\
\hline Con $\mathrm{A}+$ autologous serum & $13.55 \pm 5.19(3)$ & $10.16 \pm 3.9(3)$ & $30.33 \pm 7.91(10)$ \\
\hline Con A + homologous normal serum & $29.90 \pm 4.68(3)$ & - & - \\
\hline Con $\mathrm{A}+$ homologous $\mathrm{HB}_{8} \mathrm{Ag}$-positive serum & - & - & $20.41 \pm 2.62(7)$ \\
\hline Prednisone therapy* (spontaneous cytotoxicity) & - & $2.62 \pm 1.68(3)$ & - \\
\hline
\end{tabular}

Number in parenthesis represents number of patients studied.

* Patients treated with between 30 and $60 \mathrm{mg}$ of prednisone/day for a mean interval of 2.5 mo. 
presence of serum obtained from patients with $\mathrm{HB}_{\mathrm{s}} \mathrm{Ag}-$ positive acute and chronic active hepatitis $(P<0.05)$.

Con A-stimulated lymphocyte cytotoxicity in acute and chronic hepatitis. Lymphocytes from patients with acute and chronic hepatitis were stimulated by Con A. The transformed $\mathrm{T}$ cells were capable of producing a high degree of cytotoxicity against human Chang liver cells (Fig. 4). There was no difference in lymphocyte cytotoxicity induced by Con A between patients with viral hepatitis and controls. Patients with acute hepatitis had $30.43 \pm 5.37 \%$ Con A-stimulated cytotoxicity compared to $31.63 \pm 5.65 \%$ for control $(P<0.5)$. Similarly, peripheral lymphocytes from patients with $\mathrm{CAH}$ and chronic persistent hepatitis were capable of Con Astimulated cytotoxicity (Fig. 4). The mean percent lymphocyte cytotoxicity in chronic hepatitis was $39.83 \pm$ 5.0 compared to $39.16 \pm 5.81$ in controls.

Effect of autologous and homologous sera on Con $A$ stimulated lymphocyte cytotoxicity. Peripheral lymphocytes from patients with acute viral hepatitis, CAH, and normal controls were incubated with $10 \mu \mathrm{g} / \mathrm{ml}$ of Con $\mathrm{A}$ in the presence of $5 \%$ autologous serum to determine if autologous serum also inhibited Con Astimulated cytotoxicity. The results of these experiments are shown in Fig. 5 and Table II. Autologous sera markedly depressed lymphocyte cytotoxicity inducible by Con $A$ in acute hepatitis (from 32.7 \pm 6.94 to $13.55 \pm 5.19 \%$ ) and in $\mathrm{CAH}$ (from $34.0 \pm 8.73$ to $10.16 \pm 3.91 \%$ ). Homologous $\mathrm{HB}_{\mathrm{s}} \mathrm{Ag}$-positive serum also inhibited Con A-stimulated cytotoxicity in normal

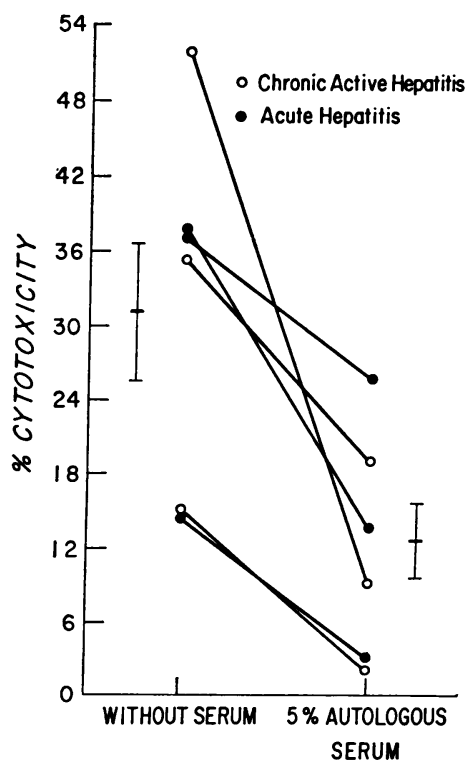

FIGURE 5 The depressive effect of $5 \%$ autologous serum on Con A-maximally stimulated lymphocyte cytotoxicity in patients with acute viral hepatitis and $\mathrm{CAH}$ (72-h incubation).

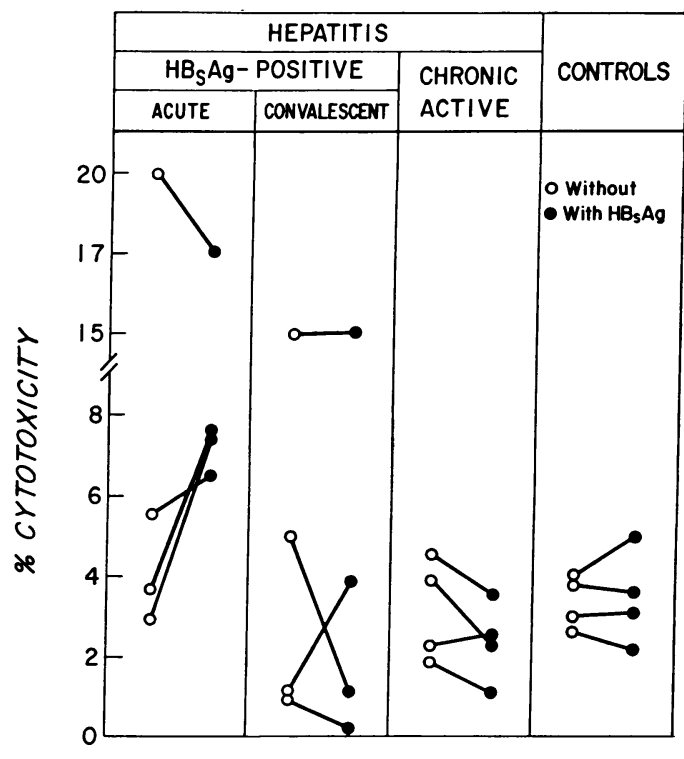

Figure 6 Effect of purified $\mathrm{HB}_{\mathbf{8}} \mathrm{Ag}$ demonstrating no consistent stimulation or inhibition of lymphocyte cytotoxicity in acute $\mathrm{HB}_{\mathrm{s}} \mathrm{Ag}$-positive hepatitis, $\mathrm{CAH}$, and controls (72-h incubation).

control lymphocytes $(P<0.001)$. There was, however, no inhibition by autologous serum (36.04 \pm 7.61 vs. $30.33 \pm 7.91 \%$ ). Finally, homologous normal serum had no effect on Con A-induced lymphocyte cytotoxicity in patients with acute viral hepatitis.

Effect of purified HB.Ag on lymphocyte cytotoxicity. Patients with acute $\mathrm{HB}_{\mathrm{s}} \mathrm{Ag}$-positive hepatitis, $\mathrm{CAH}$, recovered $\mathrm{HB}_{\mathrm{s}} \mathrm{Ag}$-positive hepatitis, and normal controls were studied to determine if purified $\mathrm{HB}_{\mathrm{s}} \mathrm{Ag}$ could induce lymphocyte cytotoxicity. Lymphocytes from these individuals did not show any consistent change in cytotoxicity to human Chang liver cells (Fig. 6).

Effect of chronic administration of prednisone on Con A-stimulated cytotoxicity. Five patients with $\mathrm{CAH}$ who had been taking between 30 and $60 \mathrm{mg}$ of prednisone a day for a mean interval of 2.5 mo were studied. Three of these patients were studied before the administration of prednisone. Chronic administration of prednisone markedly inhibited Con A-stimulated lymphocyte mediated cytotoxicity. As shown in Fig. 7, lymphocyte cytotoxicity decreased from $36.0 \pm 5.4$ to $7.26 \pm 2.85 \%$ with prednisone therapy $(P<0.005)$.

Lymphocyte blast transformation. There was no difference in spontaneous tritiated thymidine incorporation by lymphocytes obtained from acute and chronic hepatitis and controls as shown in Table III. A significant inhibition of spontaneous blast transformation was observed when patient's lymphocytes were incubated for $72 \mathrm{~h}$ in $5 \%$ autologous and homologous $\mathrm{HB}_{\mathrm{s}} \mathrm{Ag}$-positive serum. Additionally $5 \%$ autologous 


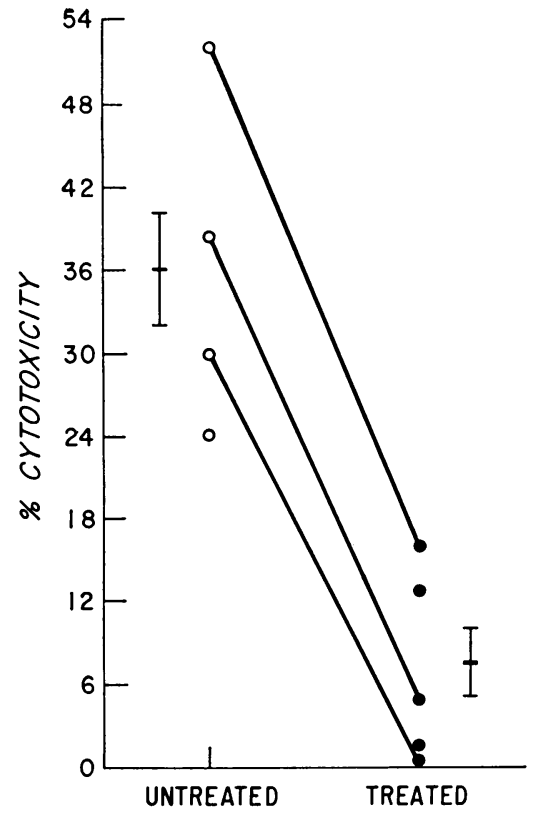

FIGURE 7 Inhibition of Con A-stimulated lymphocyte cytotoxicity by prednisone in patients receiving prednisone therapy for CAH (72-h incubation).

normal serum had an inhibitory effect on blast transformation in normal control lymphocytes but did not depress lymphocyte cytotoxicity.

Lymphocytes from patients with acute and chronic hepatitis were stimulated by Con A inducing blast transformation. There was no difference in lymphocyte blast transformation between patient lymphocytes and controls. Autologous serum depressed Con A-stimulated blastogenesis in both patients and controls. Similarly, homologous $\mathrm{HB}_{\mathrm{s}} \mathrm{Ag}$-positive serum depressed lymphocyte transformation in controls. In contrast, when lymphocytes obtained from patients with acute hepatitis were incubated with homologous normal serum, there was no depression of blastogenesis. Purified HB.Ag depressed lymphocyte blast transformation but did not show any effect on lymphocyte cytotoxicity. Finally, chronic prednisone administration had no effect on Con A-stimulated blast transformation in CAH. Prednisone, however, significantly suppressed Con A-stimulated cytotoxicity.

\section{DISCUSSION}

Lymphocyte-mediated cytotoxicity is a property of the thymus-dependent or T-lymphocyte population of lymphocytes. Plant lectins, such as PHA, pokeweed mitogen, and Con $\mathrm{A}$, all induce $\mathrm{T}$-lymphocyte blast transformation and these "activated" cells are cytotoxic to target cells in vitro (7-10). Similarly, purified protein derivative and other antigens may stimulate blast transformation and cytotoxicity in previously sensitized lymphocytes $(11,12)$. In the present study, it was determined that circulating lymphocytes from patients with acute and chronic hepatitis, in the absence of human sera, were spontaneously cytotoxic to human Chang liver target cells. Target cell lysis was most evident in brief 6-h lymphocyte incubation experiments; lower but still significant cytotoxicity was also demonstrated in

TABLE III

Effect of Various Sera on Lymphocyte Blast Transformation

\begin{tabular}{|c|c|c|c|c|}
\hline \multirow{3}{*}{$\begin{array}{l}\text { Incubation conditions } \\
\text { Control culture, cpm. }\end{array}$} & \multicolumn{4}{|c|}{ Lymphocyte donor group } \\
\hline & Normal & AH & САH & CAH on prednisone* \\
\hline & $.881 \pm 200(9)$ & $2,943 \pm 1,405(10)$ & $994 \pm 412(5)$ & $458 \pm 123(5)$ \\
\hline Con A $(10 \mu \mathrm{g} / \mathrm{ml})$ & $31.3 \pm 4.56(9) \ddagger$ & $27.2 \pm 8.2(10)$ & $28.6 \pm 6.96(5)$ & $24.8 \pm 4.8$ \\
\hline $\mathrm{HB}_{\mathrm{B}} \mathrm{Ag} \S$ & $1.35 \pm 0.3(5)$ & $0.7 \pm 0.1(8)$ & $0.6 \pm 0.1(4)$ & $0.6 \pm 0.2(2)$ \\
\hline Homologous serum\| & $0.74 \pm 0.2(9)$ & $0.6 \pm 0.1(9)$ & $0.7 \pm 0.1(5)$ & $0.6 \pm 0.1(5)$ \\
\hline Autologous serum $\|$ & $0.45 \pm 0.1(9)$ & $0.6 \pm 0.1(9)$ & $0.8 \pm 0.1(5)$ & $0.6 \pm 0.1(5)$ \\
\hline Con $\mathrm{A}+$ autologous serum & $12.4 \pm 3.7(3)$ & $6.8 \pm 3.0$ & $7.8 \pm 0.9(2)$ & $2.4 \pm 0.9$ \\
\hline Con A + homoglogous normal serum & - & $34.8 \pm 8.8(3)$ & - & - \\
\hline Con $\mathrm{A}+$ homologous $\mathrm{HB}_{8} \mathrm{Ag}$-positive serum & $5.6 \pm 0.38(3)$ & - & - & - \\
\hline
\end{tabular}

All cultures contain $2.0 \times 10^{6}$ lymphocytes in RPMI media with $10 \%$ heat-inactivated calf serum plus penicillin (100 U/ml). Streptomycin $(100 \mu \mathrm{g} / \mathrm{ml})$ and $40 \mathrm{mmol}$ glutamine and were done in triplicate for each experimental situation. They were kept at $37^{\circ} \mathrm{C}$ in a humidified atmosphere of $5 \% \mathrm{CO}_{2}$ in air for $72 \mathrm{~h} .18 \mathrm{~h}$ before termination of the experiment, $2 \mu \mathrm{Ci}$ of $\left[{ }^{3} \mathrm{H}\right]$ thymidine $(20 \mathrm{Ci} / \mathrm{mmol})$ was added to each culture. See Methods for determination of counts per minute per culture. AH, acute hepatitis. * These patients were treated with $30-60 \mathrm{mg}$ of prednisone/day for a mean interval of $2.5 \mathrm{mo}$

¥ The values are the mitotic index : mean counts per minute in experimental cultures divided by the mean counts per minute in the untreated cultures (control cultures). Number in parenthesis represents the number of patients studied.

\& Purified $\mathrm{HB}_{\mathrm{s}} \mathrm{Ag}$ 1:100 dilution of stock solution (see text).

$\|$ Autologous and homologous serum added at a concentration of $5 \%$. 
72-h incubation studies. The observed difference in spontaneous cytotoxicity at 6 and $72 \mathrm{~h}$ probably represents some loss of lymphocyte viability at $72 \mathrm{~h}$ since only $80 \%$ of these lymphocytes in culture excluded trypan blue. Human serum was replaced by heat-inactivated $\left(56^{\circ} \mathrm{C}\right.$ for $\left.45 \mathrm{~min}\right)$ fetal calf serum in these experiments. Therefore, the target cells were never exposed to human cytotoxic antibody $(13,14)$. This observed spontaneous cytotoxicity in acute viral hepatitis in the absence of human serum suggested in vivo T-lymphocyte activation.

There was no difference in Con A-stimulated cytotoxicity between lymphocytes from patients with acute and chronic hepatitis and normal controls in the absence of human sera; implying functionally intact $T$ lymphocyte populations in both groups. There was a substantial difference between Con A-stimulated cytotoxicity and spontaneous lymphocyte cytotoxicity in this study. This observed difference may be due to the nonspecific stimulation by Con A of a larger lymphocyte population in vitro. Inhibition of $\mathrm{PHA}$-induced lymphocyte blast transformation, when incubated in the absence of autologous sera, has been reported early in the course of acute viral hepatitis $(15,16)$. Lymphocyte unresponsiveness was a presumed early direct effect of hepatitis virus on circulating lymphocytes because PHA-induced lymphocyte blast transformation returned to control levels 7-10 days after the onset of jaundice. Most of our patients were studied 7-14 days after the onset of jaundice which may account for a normal T-lymphocyte response to Con A. It is also possible that the method used for lymphocyte separation selected a different lymphocyte population. Furthermore, PHA and Con A may stimulate different subpopulations of lymphocytes $(9,17,18)$.

Autologous and homologous HB.Ag-positive sera have a depressant effect on T-lymphocyte-mediated spontaneous cytotoxicity in acute and chronic hepatitis. The effect is observed in both 6- and 72-h incubation studies. Similarly, autologous $\mathrm{HB}_{\mathrm{s}} \mathrm{Ag}$-positive sera significantly suppressed Con A-stimulated lymphocyte cytotoxicity in both acute and chronic hepatitis as shown in Fig. 5. Indeed, homologous HB.Ag-positive serum inhibited Con A-stimulated cytotoxicity in normal control lymphocytes, but autologous normal serum had no such effect. Furthermore, homologous normal serum had no effect on Con A-stimulated lymphocyte cytotoxicity in acute viral hepatitis as shown in Table II. These studies indicate that circulating inhibitory factor(s) are present in sera of patients with acute and chronic hepatitis, which nonspecifically depress cytotoxicity in both hepatitis patients and controls. These inhibitory factor $(s)$ in acute viral hepatitis were found to disappear after recovery.
Homologous sera obtained from patients with acute viral hepatitis, alcoholic hepatitis, primary biliary cirrhosis, asymptomatic HB.Ag antigenemia, halothane hepatitis, and extrahepatic biliary obstruction inhibit PHA-induced proliferation of lymphocytes obtained from healthy individuals (19-24). Moreover, normal serum also contains factors that inhibit PHA-stimulated blast transformation and there is evidence that the inhibiting factor in normal serum may be an $\alpha_{3}$ globulin (25). We found that normal serum depressed spontaneous and Con A-stimulated lymphocyte blast transformation in controls but had no effect on lymphocyte cytotoxicity. However, the identification and characterization of these circulating serum inhibitors of lymphocyte blast transformation in acute and chronic liver disease has not been reported. Our study provides additional evidence that very small amounts (5\%) of autologous and homologous $\mathrm{HB}_{\mathrm{s}} \mathrm{Ag}$-positive sera contain inhibitory factors that not only depress lymphocyte blast transformation but also substantially reduce lymphocyte-mediated cytotoxicity.

T-lymphocyte function as measured by PHA-induced blast transformation and leukocyte migration inhibition has been reported to be abnormal in $\mathrm{HB} . \mathrm{Ag}$-positive patients with chronic active and chronic persistent hepatitis (1-3). In these studies, however, autologous sera was a component in the assay. Other studies have shown that sera from such patients has an inhibitory effect on PHA-stimulated lymphocyte blast transformation in both patients and normal controls suggesting that lymphocyte function may not be abnormal (26-28). Furthermore, PHA and Con A are not exclusively T-lymphocyte mitogens in man since both bone marrowderived (B lymphocytes) and T-lymphocytes blast transform in the presence of these agents $(29,30)$. We could detect no difference in Con A-stimulated blast transformation and cytotoxicity between patients with acute and chronic active hepatitis and controls in the absence of autologous serum. Lymphocyte function as measured by in vitro Con A stimulation appears intact in patients with CAH. Indeed, the effect of serum factor (s) on lymphocyte stimulation should be assessed before any conclusions are reached regarding in vitro lymphocyte function.

Homologous HBaAg-positive serum has been reported to induce blast transformation in lymphocytes from patients recovered from hepatitis $B$, suggesting prior lymphocyte sensitization by HB.Ag (31, 32). Purified HB.Ag, when incubated with lymphocytes for 3 and 6 days, failed to stimulate either blast transformation or cytotoxicity in these lymphocytes from our patients who had recovered from hepatitis $B$ and were HB.Ag-negative at the time of study. This preparation of antigen was added to the lymphocyte incubation at four different concentrations. Our study would suggest 
that factor(s) other than $\mathrm{HBaAg}_{\mathrm{A}} \mathrm{Are}$ involved in the stimulation of recovered hepatitic patient lymphocytes.

Corticosteroid therapy has achieved widespread clinical use in diseases where immunologic factors appear to play a role in the pathogenesis (33). In vitro cellular immune reactions can be broadly divided into an inductive phase, which involves antigen recognition and lymphocyte proliferation, and the effector phase of which lymphocyte-mediated cytolysis is an example (34). In vitro studies with human lymphocytes suggest that corticosteroids abolish the effector phase of cellmediated immunity and enhances the induction phase (35). Short-term administration of corticosteroids transiently reduce the absolute number of circulating $T$ lymphocytes in normal individuals $(17,36)$. Corticosteroids also selectively inhibit antigen and lectin induced blast transformation of T-lymphocyte subpopulations (17). Our in vitro study demonstrates that chronic prednisone therapy in patients with $\mathrm{CAH}$ has a marked inhibitory effect on the effector cytolytic phase of cellmediated immunity. In vivo depression of spontaneous lymphocyte cytotoxicity by prednisone offers one explanation for the often observed beneficial effect of corticosteroids on the clinical, biochemical, and histological features of $\mathrm{CAH}$ (37).

\section{ACKNOWLEDGMENTS}

This work was supported in part by grants from the American Cancer Society (IM-14B), the National Institutes of Health (CA-12389, AM-03014, CA-14294), and The National Ileitis and Colitis Foundation.

\section{REFERENCES}

1. Dudley, F. J., V. Giustino, and S. Sherlock. 1972. Cell-mediated immunity in patients positive for hepatitisassociated antigen. Br. Med. J. 4: 754-756.

2. Dudley, F. J., R. A. Fox, and S. Sherlock. 1972. Cellular immunity and hepatitis-associated, Australia antigen liver disease. Lancet. 1: 723-726.

3. Giustino, V., F. J. Dudley, and S. Sherlock. 1972. Thymus-dependent lymphocyte function in patients with hepatitis-associated antigen. Lancet. 2: 850-853.

4. Nielsen, J. O., O. Dietrichson, P. Elling, and P. Christoffersen. 1971. Incidence and meaning of persistence of Australia antigen in patients with acute viral hepatitis: development of chronic hepatitis. N. Engl. J. Med. 285: 1157-1161.

5. Sutnick, A. I., W. T. London, and B. S. Blumberg. 1973. Lymphocyte transformation and persistent Australia antigen. Lancet. 1: 1124.

6. Vyas, G. N., and N. R. Shulman. 1970. Hemagglutination assay for antigen and antibody associated with viral hepatitis. Science (Wash. D. C.). 170: 332-333.

7. Holm, G., and P. Perlmann. 1967. Quantitative studies on phytohaemagglutinin-induced cytotoxicity by human lymphocytes against homologous cells in tissue culture. Immunology. 12: 525-536.

8. Douglas, S. D., R. M. Kamin, and H. H. Fudenberg. 1969. Human lymphocyte response to phytomitogens in vitro: normal, agammaglobulinemic and paraproteinemic individuals. J. Immunol. 103: 1185-1195.

9. Holm, G., and P. Perlmann. 1967. Cytotoxic potential of stimulated human lymphocytes. J. Exp. Med. 125: 721-736.

10. Stobo, J. D., A. S. Rosenthal, and W. E. Paul. 1972. Functional heterogeneity of murine lymphoid cells. I. Responsiveness to and surface binding of concanavalin $\mathrm{A}$ and phytohemagglutinin. J. Immunol. 108: 1-17.

11. Lundgren, G. 1970. In vitro cytotoxicity by human lymphocytes from individuals immunized against histocompatibility antigens. I. Kinetics and specificity of the reaction. Influence of metabolic inhibitors and antilymphocyte serum. Clin. Exp. Immunol. 6: 661-670.

12. Amino, N., and L. J. Degroot. 1973. A sensitive microassay system for lymphocyte-mediated cytotoxicity induced by PHA (phytohemagglutinin) and PPD (purified protein derivative). J. Immunol. 111: 464-471.

13. Paronetto, F., M. Gerber, and S. J. Vernace. 1973. Immunologic studies in patients with chronic active hepatitis and primary biliary cirrhosis. I. Cytotoxic activity and binding of sera to human liver cells grown in tissue culture. Proc. Soc. Exp. Biol. Med. 143: 756760.

14. MacLennan, I. C. M. 1972. Antibody in the induction and inhibition of lymphocyte cytotoxicity. Transplant. Rev. 13: 67-91.

15. Willems, F. Th. C., J. L. Melnick, and W. E. Rawls. 1969. Viral inhibition of the phytohemagglutinin response of human lymphocytes and application to viral hepatitis. Proc. Soc. Exp. Biol. Med. 130: 652-661.

16. Millman, I., S. S. Agarwal, S. J. Bugbee, B. S. Blumberg, and L. A. Loeb. 1971. Lymphocyte transformation and hepatitis. II. Lack of direct in vitro inhibition by purified Australia antigen. Proc. Soc. Exp. Biol. Med. 138: 198-203.

17. Fauci, A. S., and D. C. Dale. 1974. The effect of in vivo hydrocortisone on subpopulations of human lymphocytes. J. Clin. Invest. 53 : 240-246.

18. Stobo, J. D., and W. E. Paul. 1973. Functional heterogeneity of murine lymphoid cells. III. Differential responses of $\mathrm{T}$ cells to phytohemagglutinin and concanavalin $\mathrm{A}$ as a probe for $\mathrm{T}$ cell subsets. J. Immunol. 110: 362-375.

19. Newberry, W. M., J. W. Shorey, J. P. Sanford, and B. Combes. 1973. Depression of lymphocyte reactivity to phytohemagglutinin by serum from patients with liver disease. Cell. Immunol. 6: 87-97.

20. Fox, R. A., F. J. Dudley, M. Samuels, J. Milligan, and S. Sherlock. 1973. Lymphocyte transformation in response to phytohaemagglutinin in primary biliary cirrhosis: the search for a plasma inhibitory factor. Gut. 14 : 89-93.

21. Hsu, C. C. S., and C. M. Leevy. 1971. Inhibition of PHA-stimulated lymphocyte transformation by plasma from patients with advanced alcoholic cirrhosis. Clin. Exp. Immunol. 8: 749-760.

22. Macsween, R. N. M., and M. A. Thomas. 1973. Lymphocyte transformation by phytohaemagglutinin (PHA) and purified protein derivative (PPD) in primary biliary cirrhosis. Evidence of serum inhibitory factors. Clin. Exp. Immunol. 15: 523-533.

23. Mella, B. A., and H. F. Taswell. 1970. Suppression of leukocytic mitosis by sera of hepatitis-implicated donors. Am. J. Clin. Pathol. 53 : 141-144. 
24. Mella, B., and D. J. Lang. 1967. Leukocyte mitosis: suppression in vitro associated with acute infectious hepatitis. Science (Wash. D. C.). 155: 80-81.

25. Cooperband, S. R., H. Bondevik, K. Schmid, and J. A. Mannick. 1968. Transformation of human lymphocytes: inhibition by homologous alpha globulin. Science (Wash. D. C.). 159: 1243-1244.

26. Petri, I. B., and E. J. Mészáros. 1973. Persistence of $\mathrm{Au}-\mathrm{SH}$ antigen and lymphocyte transformation. Lancet. 2: 802-803.

27. Brooks, B. R. 1972. Cellular immunity and hepatitisassociated-antigen liver disease. Lancet. 1: 1239-1240.

28. Clot, J., O. Mathieu, S. Elharrar, M. Robinet-Levy, and J-M. Lemaire. 1973. Inhibitory effect of Australia-positive sera on in vitro-stimulated $\mathrm{T}$ lymphocytes. Lancet. 2: $576-577$.

29. Chess, L., R. P. MacDermott, and S. F. Schlossman. 1974. Immunologic functions of isolated human lymphocyte subpopulations. I. Quantitative isolation of human $\mathrm{T}$ and $\mathrm{B}$ cells and response to mitogens. J. Immunol. 113: 1113-1121.

30. Chess, L., R. P. MacDermott, and S. F. Schlossman. 1974. Immunologic functions of isolated human lymphocyte subpopulations. II. Antigen triggering of $\mathrm{T}$ and $\mathrm{B}$ cells in vitro. J. Immunol. 113: 1122-1127.

31. Laiwah, A. A. C. Y. 1971. Lymphocyte transformation by Australia antigen. Lancet. 2 : 470-471.
32. Pettigrew, N., and R. I. Russell. 1972. Hepatitis-associated, antigen-induced lymphocyte transformation in chronic hepatitic disease. Gut. 13: 852-853. (Abstr.)

33. Schwartz, R. S. 1968. Immunosuppressive drug therapy. In Human Transplantation. F. T. Rapaport and J. Dausset, editors. Grune \& Stratton, Inc., New York. 440-456.

34. Feldman, M., I. R. Cohen, and H. Wekerle. 1972. Tcell mediated immunity in vitro: an analysis of antigen recognition and target cell lysis. Transplant. Rev. 12: 57-90.

35. Cohen, I. R., L. Stavy, and M. Feldman. 1970. Glucocorticoids and cellular immunity in vitro. Facilitation of the sensitization phase and inhibition of the effector phase of a lymphocyte anti-fibroblast reaction. J. Exp. Med. 132: 1055-1070.

36. Yu, D. T. Y., P. J. Clements, H. E. Paulus, J. B. Peter, J. Levy, and E. V. Barnett. 1974. Human lymphocyte subpopulations. Effect of corticosteroids. J. Clin. Invest. 53 : 565-571.

37. Soloway, R. D., W. H. J. Summerskill, A. H. Baggenstoss, M. G. Geall, G. L. Gitnick, L. R. Elveback, and L. J. Schoenfield. 1972. Clinical, biochemical, and histological remission of severe chronic active liver disease: a controlled study of treatments and early prognosis. Gastroenterology. 63: 820-833. 